\title{
Análise da contaminação por Salmonella em ovos do tipo colonial através da reação em cadeia da polimerase
}

\author{
Analysis of Salmonella in free-range eggs through polymerase \\ chain reaction
}

\begin{abstract}
Maristela Lovato Flôres ${ }^{2}$ Vladimir Pinheiro do Nascimento ${ }^{3}$ Ivonyr Irene Tróglio Abdel Kader ${ }^{4}$ Martha Cardoso $^{5}$ Luciana Ruschel dos Santos ${ }^{5}$ Rui Fernando Félix Lopes ${ }^{6}$ Vera Beatriz Wald Taylor Marcelo Corrêa Barbosa ${ }^{8}$
\end{abstract}

\section{RESUMO}

A identificação de poedeiras comerciais infectadas por salmonelas tem sido um dos pontos fortes da profilaxia $e$ conseqüente redução de surtos de salmonelose em humanos associados ao consumo de ovos, sendo que a análise dos ovos pode ser mais um dos pontos de detecção da infecção, que, muitas vezes, cursa sem sinais clínicos. A Reação em Cadeia da Polimerase (PCR) parece ser uma estratégia útil para detecção de Salmonella, pois vários autores têm utilizado a PCR para verificar a presença da bactéria em carnes, fezes, tecidos, sangue, leite e ovos, com diferentes metodologias de manipulação das amostras. Foram analisados 360 ovos, procedentes de dez propriedades rurais, produtoras de ovos tipo colonial, no distrito de Camobi, em Santa Maria - RS. Os ovos foram divididos em grupos de seis, totalizando sessenta amostras. O exame bacteriológico foi realizado conforme metodologia preconizada pelas normas técnicas e a metodologia de extração de DNA pelo fenol-clorofórmio. A $P C R$ foi realizada para a amplificação de um fragmento de DNA de 284 pb. A análise dos resultados não demonstrou diferença significativa entre a PCR e o bacteriológico. Todas as amostras positivas ao bacteriológico foram positivas na $P C R$, sendo que essa última detectou duas amostras a mais, devido a sua alta sensibilidade e especificidade, especialmente quando é sabido que os ovos apresentam uma população microbiana mista que, muitas vezes, impede o isolamento adequado das salmonelas no bacteriológico pela competição com a flora bacteriana normalmente presente.

Palavras-chave: Salmonelas, ovos coloniais, PCR.

\section{ABSTRACT}

The identification of salmonella infection in commercial poultry has been one of the strong points of prophylaxis and consequent reduction of salmonellosis outbreaks in humans associated to consumption of eggs, considering that the analysis of the eggs can be one more point of detection of infection, which for many times appear without clinical signs. The Polymerase Chain Reaction (PCR) seems to be a useful strategy for Salmonella detection, because various authors have used the PCR to verify the presence of bacteria in meat, feces, tissues, blood, milk and eggs, with different methods of manipulation of samples. We have analyzed 360 eggs from ten farms, producers of free range-eggs, in the district of Camobi, in Santa Maria - RS - Brasil. The eggs were grouped in pools of six, totaling sixty samples. The bacteriological exam was done in compliance with the method preconized by the technical rules and the method for extraction of DNA was by phenol-chloroform. The PCR was performed for the amplification of a $284 \mathrm{bp} D N A$ fragment. The analysis of the results do not show significant difference between the PCR and the bacteriological exam. All positive samples in the

${ }^{1}$ Parte da Tese de Doutorado do primeiro autor, no Programa de Pós-graduação em Ciências Veterinárias da Universidade Federal do Rio Grande do Sul (UFRGS).

${ }^{2}$ Médico Veterinário, Professor Adjunto, Doutor, Departamento de Medicina Veterinária Preventiva, Centro de Ciências Rurais, Universidade Federal de Santa Maria (UFSM), 97105-900, Santa Maria, RS. E-mail: patoaves@ccr.ufsm.br. Autor para correspondência.

${ }^{3}$ Médico Veterinário, Professor Adjunto, PhD., CDPA/UFRGS, Orientador.

${ }^{4}$ Farmacêutico, Professora Titular, Doutor, FFFCMPA, Co-Orientador.

${ }^{5}$ Médico Veterinário, CDPA/UFRGS.

${ }^{6}$ Médico. Veterinário, Professor Adjunto, Doutor, DCM/ICBS/UFRGS.

${ }^{7}$ Professor Adjunto, Faculdade de Veterinária, UFRGS.

${ }^{8}$ Acadêmico de Medicina Veterinária, UFSM, Bolsista PIBIC/CNPq/UFSM. 
bacteriological exam were also positive by $P C R$, however the $P C R$ detected more two samples due to higher sensitivity and specificity, specially when it is known that the eggs show a mixed population of germs that many times difficult isolation of salmonellas in the bacteriological exam because of the competition with normal flora bacteria.

Key words: Salmonellas, free-range eggs, PCR

\section{INTRODUÇÃO}

A aplicação da metodologia da reação em cadeia da polimerase (PCR), na detecção de alimentos, animais e pessoas infectadas, é uma estratégia atualmente utilizada e citada por muitos autores como eficiente e rápida. Métodos para detecção rápida de Salmonella têm sido desenvolvidos, nos últimos anos, tais como ELISA, imunodifusão, hibridização do DNA, aglutinação em látex e imunofluorescência, porém, muitos desses métodos apresentam problemas de sensibilidade e/ou especificidade, que limitam a sua aceitação (BLACKBURN, 1993).

A Reação em Cadeia da Polimerase (PCR) é uma estratégia útil para detecção de Salmonella em carnes, fezes, tecidos, sangue e leite, com diferentes metodologias de manipulação das amostras para inativar possíveis inibidores da reação, como sais biliares, hemoglobina e componentes sangüíneos (AABO et al.,1993; COHEN et al., 1994; FADL et al., 1995). Os resultados de WOODWARD \& KIRWAN, (1996), MC ELROY et al. (1996) e RIJPENS et al. (1999) demonstram que a PCR pode ser usada para detecção de salmonelas em ovos experimentalmente infectados.

PERESI et al. (1998), estudando os fatores epidemiológicos envolvidos em 23 surtos de salmoneloses ocorridos no estado de São Paulo, observaram que o agente foi veiculado em 22 (95,7 \%) deles por alimentos contendo ovos. Nos relatórios das enfermidades transmitidas por alimentos da Divisão de Vigilância Sanitária da SSMA/RS, 32,3\% das toxinfecções alimentares envolveram, direta ou indiretamente, os ovos. Do total de 136 surtos, em 35,3\% houve identificação de Salmonella sp. (PINTO, 1999).

Em 1.050 ovos de aves contaminadas artificialmente com $S$. Enteritidis e o vírus da doença de Gumboro, PHILLIPS \& OPTIZ (1995) isolaram a bactéria em $88(8,3 \%)$ cascas, $5(0,48 \%)$ albuminas e $2(0,16 \%)$ gemas. As taxas de infecção observadas por FEHLHABER \& JANETSCHKE(1995), em 5.339 ovos, foram de $4,19 \%$ na casca e $0,20 \%$ no interior de ovos provenientes de aves infectadas. Por outro lado, em 22.766 ovos de mercado analisados pelos mesmos autores, $0,47 \%$ foram positivos na casca e $0,22 \%$ no seu interior.
Usando um par de oligonucleotídeos do gene invA, RAHN et al. (1992) detectaram com sucesso 626 cepas de Salmonella, de 630 amostras testadas, valendo-se de uma colônia isolada e incorporada direto na PCR, com uma sensibilidade de 99,4\% e especificidade de 100\%. Da mesma forma, SCHARANK et al. (2000) referem-se à elevada sensibilidade e especificidade quando usaram a técnica para identificar a presença de Salmonella em produtos avícolas.

O objetivo deste trabalho foi aplicar a técnica de PCR na detecção de salmonelas em ovos comerciais, do tipo colonial, obtidos diretamente de produtores rurais de Santa Maria - RS, comparando-a com o exame bacteriológico convencional.

\section{MATERIALEMÉTODOS}

A execução deste trabalho ocorreu junto aos laboratórios de Bacteriologia e de Biologia Molecular do Centro de Diagnóstico e Pesquisa em Patologia Aviária (CDPA), da Faculdade de Veterinária-UFRGS. Foram analisados 360 ovos procedentes de dez propriedades rurais, produtoras de ovos tipo colonial, no distrito de Camobi, em Santa Maria RS. Esses foram divididos em grupos de seis, previamente desinfetados com álcool iodado, abertos e coletados apenas seu conteúdo, pois, conforme FLORES et al (2001), a casca pode determinar influência na técnica da PCR.

O exame bacteriológico foi realizado, conforme metodologia preconizada pelas normas técnicas (BRASIL, 1995; BRASIL, 1997). Para a PCR, foram utilizadas alíquotas de amostras coletadas após 24 horas de incubação em água peptonada (AP) e após 24 horas de incubação em caldo Rappaport-Vassiliadis (RV).

A extração do DNA, para análise por PCR, foi realizada utilizando-se o protocolo de fenolclorofórmio, descrito por SAMBROOK et al. (1989), modificado por SANTOS et al. (1999). O par de oligonucleotídeos iniciadores utilizados para amplificação do DNA foi sintetizado com base nas seqüências 5' GTG AAA TTA TCG CCA CGT TCG GCG CAA 3' (primer 1) e 5' TCA TCG CAC CGT CAA AGG AAC C 3' (primer 2), proposta por RAHN et al. (1992) para amplificar um fragmento de $284 \mathrm{pb}$ do gene invA de Salmonella sp.

A PCR foi realizada em tubos cônicos de polipropileno de $0,5 \mathrm{~mL}$ contendo $1 \mu \mathrm{L}$ da amostra, no volume total de $25 \mu \mathrm{L}$, com concentrações finais de $1,5 \mathrm{mM}$ de $\mathrm{MgCl}_{2}$ (MERCK); 0,4mg de BSA

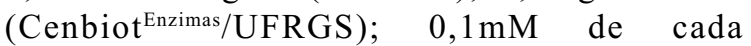
deoxinucleotídeos (dATP, dCTP, dGTP e dTTP; Gibco $\mathrm{BRL}$ ); 0,2pmol de cada oligonucleotídeo iniciador 
(Gibco BRL); e $0,5 \mu \mathrm{L}$ de Taq DNA Polimerase (Cenbiot ${ }^{\text {Enzimas }} / \mathrm{UFRGS}$ ) de um frasco contendo $1 \mathrm{U} / \mathrm{mL}$. O protocolo de amplificação foi realizado em termociclador Perkin Elmer Gene Amp PCR System 2400 (Perkin Elmer, New Jersey, USA) utilizando-se uma etapa de desnaturação inicial de $94^{\circ} \mathrm{C}$, por 5 minutos, seguida de trinta ciclos consecutivos de $94^{\circ} \mathrm{C}$, por 1 minuto para desnaturação, $54^{\circ} \mathrm{C}$, por 30 segundos, para o anelamento, e $72^{\circ} \mathrm{C}$, por 1 minuto na extensão, com uma etapa de extensão final a $72^{\circ} \mathrm{C}$ por 7 minutos.

A análise dos fragmentos amplificados foi executada por eletroforese durante 40 a 45 minutos a $90 \mathrm{~V}$ e $43 \mathrm{~mA}$, em gel de agarose a $2 \%$ preparado em TBE (Tris base, ácido bórico, EDTA), corado com brometo de etídio $(0,5 \mu \mathrm{g} / \mathrm{mL})$. O marcador de peso molecular utilizado foi DNA Ladder 100pb (Gibco BRL). A observação de fragmentos de DNA na altura de $284 \mathrm{pb}$, após a migração em eletroforese, foi realizada em aparelho transiluminador (Pharmacia LKB, Macrovue) quando os resultados foram fotografados com câmara polaróide.

Os resultados foram analisados estatisticamente pelos testes do Qui-quadrado e de Correlação segundo o programa SAS (1996), considerando-se um nível de significância de 5\%. Ainda, os resultados foram avaliados segundo metodologia preconizada por CORTES (1993) quanto a análise quantitativa da sensibilidade, especificidade e coeficiente global do teste.

\section{RESULTADOS E DISCUSSÃO}

Nas tabelas 1, 2 e 3, podem ser observados os resultados das análises bacteriológicas e da PCR, em amostras de ovos obtidos diretamente em propriedades de ovos do tipo colonial. A análise das tabelas mostra que as taxas de contaminação obtidas ficaram abaixo do esperado, ao redor de $10 \%$, pois se tratavam de ovos provenientes de poedeiras criadas

Tabela 1 - Resultados das Reações em Cadeia da Polimerase realizadas em 60 grupos de seis ovos coloniais, coletados após 24 horas de incubação em água peptonada (AP) e após 24 horas em caldo RappaportVassiliadis (RV), submetidas à extração do DNA pelo método do fenol-clorofórmio.

\begin{tabular}{lcccc}
\hline \multirow{2}{*}{ Resultado } & \multicolumn{2}{c}{ AP } & \multicolumn{2}{c}{ RV } \\
& $\mathrm{N}$ & $\%$ & $\mathrm{n}$ & $\%$ \\
\hline Positivo & 2 & 3,32 & 3 & 4,98 \\
Negativo & 58 & 96,68 & 57 & 95,02 \\
Total & 60 & 100,00 & 60 & 100,00 \\
\hline
\end{tabular}

sem normas sanitárias adequadas, em locais nos quais não havia controle ambiental, permitindo o contato estreito das aves e ovos com fatores de contaminação.

HUMPHREY \& PATH (1997) citam que a freqüência de produção de ovos infectados é baixa em poedeiras comerciais e que, quando infectados, eles contêm poucas salmonelas. Ainda, ZEIDLER (1996) observou que o número de ovos infectados é muito baixo e que nunca ultrapassaria $5 \%$ dos ovos produzidos em granjas sabidamente contaminadas. LANGONI et al. (1995) encontraram 3,92\% de amostras positivas examinando ovos comerciais no Município de Botucatu - SP.

Os dados demonstram a detecção de $1,66 \%$ amostras contaminadas através do bacteriológico (Tabela 2), ou seja, apenas uma amostra em sessenta apresentava salmonela, que foi identificada como Salmonella Gallinarum, através de bioquimismo e sorologia convencional. Esta taxa é concordante com os dados relatados por ZEIDLER (1996).

A PCR mostrou-se mais eficiente e mais rápida para o monitoramento de propriedades infectadas, permitindo identificar o dobro de propriedades que o bacteriológico. Este fato é suficiente para recomendar-se esta metodologia, especialmente em granjas com vários galpões, onde a enfermidade pode espalhar-se rapidamente sem sinais claros. Com o uso de PCR, pode-se identificar os lotes infectados com rapidez, sem coletas de sangue, que podem facilitar a difusão das salmonelas.

Independente dos meios de préenriquecimento utilizados antes da extração de DNA (Tabela 1), não houve diferença significativa no número de amostras positivas detectadas na PCR, podendo-se recomendar uma pré-incubação de 24 horas em água peptonada $1 \%$ como eficiente para a obtenção da maioria das amostras de ovos positivas. A recuperação de um número maior de amostras positivas, ao prolongar-se a incubação em mais 24 horas (ou menos de 24 horas), em caldo Rappaport-Vassiliadis, deve ser utilizado na medida que o bacteriológico esteja ocorrenda em paralelo, permitindo o acesso fácil de mais uma amostra para a PCR. Para uma análise mais precisa da diferença entre utilizar apenas a incubação por 24 horas em AP1\% ou incluir algumas horas de incubação em caldo RV, o número de amostras deve, na medida do possível, ser aumentado, pois as diferenças aqui observadas não permitiram nenhuma conclusão definitiva.

A análise da tabela 2 demonstra que a PCR detectou três vezes mais amostras que o bacteriológico em ovos naturalmente infectados, concordando com as observações de BURKHATLER et al. (1996) e 
Tabela 2 - Resultados das provas bacteriológicas em comparação com a análise por Reação em Cadeia da Polimerase realizadas em 60 grupos de seis ovos coloniais, de dez (10) propriedades distintas, coletados após 24 horas de incubação em água peptonada (AP) e em 24 horas em caldo Rappaport-Vassiliadis (RV), submetidas à extração do DNA pelo método do fenolclorofórmio.

\begin{tabular}{lcccccc}
\hline \multirow{2}{*}{ Resultado } & \multicolumn{3}{c}{ Bacteriológico } & \multicolumn{3}{c}{ PCR } \\
\cline { 2 - 7 } & Prop. & Amostra & $\%$ & Prop. & Amostra & $\%$ \\
\hline Positivo & 1 & 1 & 1,66 & 2 & 3 & 4,98 \\
Negativo & 9 & 59 & 98,33 & 8 & 57 & 95,02 \\
Total & 10 & 60 & 100,00 & 10 & 60 & 100,00 \\
\hline
\end{tabular}

RIJPENS et al. (1999), os quais salientaram que os índices reais de contaminação podem estar sendo subestimados quando é usada apenas a metodologia bacteriológica convencional.

Com esses dados, se fosse calcular os riscos para o consumidor com apenas $1,66 \%$ de ovos positivos, considerando o consumo anual de 97 ovos per capital ano, no Brasil, poder-se-ia dizer que a cada 97 ovos consumidos 1,61 estarão contaminados; porém, se for considerado o valor de 4,98 \% positivos (Tabela 2), o risco de ingerir ovos contaminados aumentará para 4,83 ovos com salmonelas em cada 97. A análise não é tão simples, pois os resultados da tabela 2 foram obtidos de grupos de seis ovos. Não é possível saber quantos dos seis ovos eram positivos e o risco de não serem detectados todos os positivos usando apenas a técnica bacteriológica é uma realidade.

A análise dos resultados não demonstrou diferença significativa entre a PCR e o bacteriológico (Tabela 3). Todas as amostras positivas ao bacteriológico foram positivas na PCR, sendo que essa metodologia detectou duas amostras a mais devido a sua alta sensibilidade e especificidade, especialmente quando é sabido que os ovos apresentam uma

Tabela 3 - Comparação entre as técnicas de diagnóstico, Reação em Cadeia da Polimerase com extração pelo Fenolclorofórmio e bacteriológico, de 60 amostras provenientes de ovos do tipo colonial, analisadas pelo teste McNemar.

\begin{tabular}{lccc}
\hline Bacteriológico & \multicolumn{3}{c}{ PCR (fenol-clorofórmio) } \\
\cline { 2 - 4 } & Positivo & Negativo & Total \\
\hline Positivo & 1 & 0 & 1 \\
Negativo & 2 & 57 & 59 \\
Total & 3 & 57 & 60 \\
\hline
\end{tabular}

$p=0,1573 \quad$ Kappa $=0,487$ população microbiana mista, que, muitas vezes, impede o isolamento adequado das salmonelas no bacteriológico pela competição.

O importante é que a PCR foi tão eficiente quanto o bacteriológico, com custo e tempo significativamente menores. Uma vez que não há necessidade de ter células viáveis para obter a PCR positiva (COHEN et al., 1994), podese aumentar o número de amostras positivas em relação às obtidas no bacteriológico, sem necessariamente serem falsos positivos.

\section{CONCLUSÃO}

A análise dos resultados não demonstrou diferença significativa entre a PCR e o bacteriológico para a detecção de Salmonella em ovos, havendo concordância de diagnóstico entre as metodologias. Todas as amostras positivas ao bacteriológico foram também positivos na PCR, sendo que essa detectou duas amostras a mais.

\section{AGRADECIMENTOS}

Agradecimentos as instituições financiadoras: FAPERGS, FFFCMPA, ao CDPA/UFRGS, ao Laboratório CENBIOT $^{\text {Enzimas/ }}$ UFRGS.

\section{REFERÊNCIAS BIBLIOGRÁFICAS}

AABO, S., et al. Salmonella identification by the polymerase chain reaction. Molecular and Cellular Probes, London, v.7, p.171-178, 1993.

BLACKBURN, C. W. A review, rapid and alternative methods for the detection of Salmonella in food. Journal of Applied Bacteriology, Oxford, n.75, v.3, p.199-214,1993.

BRASIL, Portaria n. 08, 23 de janeiro de 1995. Ministério da Agricultura, do Abastecimento e da Reforma Agrária, Secretaria de Defesa Agropecuária. Método Analítico de Carcaças de Aves e Pesquisa de Salmonella. Diário Oficial [da República Federativa do Brasil], Brasília, , p.1182-1184, 27 de janeiro de 1995, Seção I, 1995.

BRASIL, Portaria n.451, de 19/09/97. Ministério da Saúde, Secretaria Nacional da Vigilância Sanitária. Aprova o Regulamento técnico e princípios gerais para o estabelecimento de critérios e padrões microbiológicos para alimentos. Diário Oficial [Da República Federativa do Brasil], Brasília, v. n. p. 21005-21012, 22 de setembro de 1997, Seção I.

BURKHATLER, P.W. et al. Detection of Salmonella spp in eggs: DNA analyses, culture techniques, and serology. Journal of AOAC International, v. 79, n.3, p.123, 1996.

COHEN, N. D. et al. Detection of Salmonella Enteritidis in feces from poultry using booster polymerase chain reaction and oligonucleotide primers specific for all members of the genus Salmonella. Poultry Science, Champaign, v.73, n.2, p.354-357, 1994. 
CORTES, J.A. Epidemiologia, conceitos e princípios fundamentais. São Paulo : Varela, 1993. 227p.

FADL, A.A.; NGUYEN, A.V.; KHAN, M.I. Analysis of Salmonella enteritidis isolates by arbritrarily primed PCR. Journal of Clinical Microbiology, Washington, v.33, n.4, p.987-989, 1995.

FEHLHABER, K.; JANESTSCHKE. Higiene veterinária de los alimentos. Zaragoza : Acribia, 1995. 669p.

FLORES, M.L. et al . Métodos de extração de DNA para a detecção de Salmonella em ovos de galinhas, com e sem casca, através da reação em cadeia pela polimerase. Ciência Rural, v.31, n.2, p.315-318, 2001.

HUMPHREY, T.J.; PATH, M.R.C. The infection of laying hens with Salmonella enteritidis PT4 and factors which influence egg contamination. In: SYMPOSIUM SALMONELLA AND SALMONELLOSIS'97, Poulfragan, França. Proceedings... França, 1997. p.305-311.

LANGONI, H. et al. Isolamento de salmonelas em ovos de galinhas oferecidos para consumo no comércio de BotucatuSP. Higiene Alimentar, São Paulo, v.37, n.9, p.45-47, 1995.

Mc ELROY, A.; COHEN, N.D.; HARGIS, B. M. Evaluation of the polymerase chain reaction for the detection of Salmonella Enteritidis in experimentally inoculated eggs and eggs from experimentally challenged hens. Journal of Food Protection, Ames, v.59, n.12, p.1273-1278, 1996.

PERESI J. T. M. et al. Surtos de enfermidades transmitidas por alimentos causados por Salmonella Enteritidis. Revista de Saúde Pública, São Paulo, v.32, n.5, p.477-483, 1998.

PHILLIPIS, R.A.; OPTIZ, H.M. Pathogenicity and persistence of Salmonella enteritidis and egg contamination in normal and infectious bursal disease virus-infected leghorn chicks. Avian Diseases, Kenette Square, v.39, p.778-787, 1995.

PINTO, A.T. Ocorrência de enfermidades bacterianas transmitidas por alimentos no estado do Rio Grande do Sul. 1999. 124f. Dissertação (Mestrado) - UFRGS.

RAHN, K. et al. Amplification of an InvA gene sequence of Salmonella typhimurium by polymerase chain reaction as a specific method of detection of Salmonella. Molecular and Cellular Probes, London, v.6, p.271-279, 1992.

RIJPENS, N. et al. Rapid detection of stressed Salmonella spp in dairy and egg products using immunomagnetic separation and PCR. International Journal of Food Microbiology, Amsterdam, v.46, p.37-44, 1999.

SAMBROOK, J.; FRITCSH, E. F.; MANIATIS, T. Molecular cloning: A laboratory manual. 2. ed. New York : Cold Spring Harbor Laboratory, 1989. 3v.

SANTOS, L. R. et al. Protocolos para a extração de DNA de Salmonella. Arquivos da Faculdade de Veterinária da UFRGS, Porto Alegre, v.27, n.2, p.93-101, 1999.

SAS, SAS INSTITUTE. Statistical guide for personal computers, Versão 7. Carry, 1996. 1686p.

SCHRANK, I.S. et al. Aplicação de método baseado em PCR para a detecção de Salmonella em produtos da Industria Avícola e em amostras clínicas. Revista Brasileira de Ciência Avícola, Supl 2, p.105, 2000.

WOODWARD, M.J.; KIRWAN, S.E. S. Detection of Salmonella enteritidis in eggs by the polymerase chain reaction. Veterinary Record, London, v.138, p.411-413, 1996.

ZEIDLER, G. Who's afraid of the Salmonella Wolf?. World Poultry, sup. special for Salmonella, v.5, p.4-9, 1996. 